\title{
If Goa is your land, which are your stories? Narrating the Village, Narrating Home*
}

Cielo Griselda Festino ${ }^{a}$

* This paper was carried out as part of the FAPESP thematic project "Pensando Goa" (proc. 2014/15657-8). The opinions, hypotheses and conclusions or recommendations expressed herein are my sole responsibility and do not necessarily reflect the ideas of FAPESP.

\begin{abstract}
Goa, India, is a multicultural community with a broad archive of literary narratives in Konkani, Marathi, English and Portuguese. While Konkani in its Devanagari version, and not in the Roman script, has been Goa's official language since 1987, there are many other narratives in Marathi, the neighbor state of Maharashtra, in Portuguese, legacy of the Portuguese presence in Goa since 1510 to 1961, and English, result of the British colonization of India until 1947. This situation already reveals that there is a relationship among these languages and cultures that at times is highly conflictive at a political, cultural and historical level. In turn, they are not separate units but are profoundly interrelated in the sense that histories told in one language are complemented or contested when narrated in the other languages of Goa. One way to relate them in a meaningful dialogue is through a common metaphor that, at one level, will help us expand our knowledge of the points in common and cultural and literary differences among them all. In this article, the common metaphor to better visualize the complex literary tradition from Goa will be that of the village since it is central to the social structure not only of Goa but of India. Therefore, it is always present in the many Goan literary narratives in the different languages though from perspectives that both complement and contradict each other.
\end{abstract}

Keywords: Goa, multilingualism, literature, village.

a Professora titular da Universidade Paulista, cielofestino@gmail.com. 


\section{Introduction}

Goa is a former Portuguese colony situated on the West coast of the Indian subcontinent. It is a multicultural community with a vast archive of narratives in Konkani, Marathi, English and Portuguese. While Konkani can be regarded as the "mother tongue of Goa" (DESAI, 2000, p. 469) and its version in the Devanagari script has been Goa's official language since 1987, there are also many narratives in Marathi, the language of the neighboring state of Maharashtra that, at some point, fought for supremacy in Goa, in Portuguese, a legacy of the Portuguese presence in Goa, and in English, spoken both by the Goans at home and in the diaspora. Melo Furtado (2000, p. 478) explains that soon after the end of the Portuguese colonial period marked by the integration of Goa into the Indian Union in 1961, the Portuguese language was replaced by English causing no little wonder among the Goan Catholic community that was being educated at the Portuguese Lyceum. Evidently, these languages are not separate units, but are deeply intertwined in the sense that the stories narrated in one might be contested or complemented in another. Thus, stories which had been commonly told in Portuguese up to 1961, soon found their way into English or the other languages of Goa. Paul Melo e Castro ${ }^{1}$ illustrates this case by referring to the short story "Dust" (2002) by the Goan writer Heta Pandit. Foreseeing the deep political changes that were about to happen in Goa, the narrator was educated in English, while all the members of the family in the story spoke Portuguese. Therefore, when she tells the story of her ancestors she does it in English. Another example suggested by Melo e Castro is that of the novel The Sting of Peppercorn. Antonio Gomes's A Novel Set in Goa (2010), whose plot is about the fall of a Catholic family in the village of Loutolim, is written in English though its characters speak Portuguese.

Jacques Rancière (2005, p. 17-18) says that art is a public space, a realm in which beliefs are recreated and become visible. Art reveals the link between the history of the community and the stories being narrated. Art, thus, creates what he defines as "a community of sense":

1 Personal communication at USP, São Paulo, Brazil, on December 16th, 2015.
I do not take the phrase "community of sense" to mean a collectivity shaped by some common feeling. I understand 
it as a frame of visibility and intelligibility that puts things or practices together under the same meaning which shapes thereby a certain sense of community. A community of sense is a certain cutting out of space and time that binds together practices, forms of visibility, and patterns of intelligibility. I call this cutting out and this linkage a partition of the sensible. (RANCIÈRE, 2009, p. 31).

A community of sense, according to Rancière, is not simply an ethos, a common being together that results in a fixed number of interrelated acts. It implies a partition of the sensible, in other words, a polemical distribution of the ways of being and a reflection on how much each one takes of the common space. In the case of Goa, a partition of the sensible would mean how much of this community of sense each literary tradition, in the different languages, takes up. In November 2015, there was a short story competition sponsored by Fundação Oriente in Panjim, Goa. Eighty-one short stories were submitted: fortyfour in English, nineteen in Konkani, seventeen in Marathi and one in Portuguese. The number of stories in each language might be considered as being significant in the sense that it shows the importance of each language within the community. The people of Goa, though, are familiar with more than one language: they may speak one language at home, learn another one at school and write their stories in a third one. What is more relevant than the number of stories in each language is perhaps the fact that they do not signify in isolation but in terms of each other in an endless process of contesting and rewriting. What matters is not in what language the best story was written, but that there are stories in all the languages that talk about the same community but from a different perspective.

It might even be argued that the most significant meanings of these narratives become overt, mainly when they are read in counterpoint, because they install themselves at the frontier that separates "Them" from "Us", as Richard Chamberlin (2004, p. 203) would say. This kind of approach to the narrative leads the reader not only to see his own narratives in perspective but also to question them, since after telling them and listening to them so many times we tend to forget how arbitrary they are. This is the moment when the difference between "their stories" and "our stories" is transformed into a "ceremony of belief" as Chamberlin points out: 
The moment when "yours" and "mine" disappear and mystery and clarity converge, when we cannot tell whether we have surrendered ourselves or are still separate, when intensity has a casual quality to it... and once we have recognized it in our culture, we can identify it in others. That's the beginning of moving beyond 'us' and 'them'. (CHAMBERLIN, 2004, p. 203)

It is in the act of believing in these stories, rather than the beliefs embodied in them, in the telling rather than the tale, that we cross barriers.

One way to bring together all these different narratives in a meaningful dialogue is through a common metaphor that will help us expand our horizons of understanding cultural affinities and differences. In this paper, the common metaphor to visualize the community of sense composed by the literary narratives from Goa will be that of the Goan village and its surrounding countryside, because villages are always at the forefront or the background of many Goan writers' short stories in all their different languages and genres. In turn, because Goan literary tradition in the four languages is so vast, the analysis will be limited to the short story, one of the genres of greatest circulation in Goa.

Historically, the village has been central to India's social structure. Mahatma Gandhi has been quoted as saying that "India lives in the villages" (Sharma, 2015). For him, the development of the villages in India was the development of the country. Likewise, Goa's social structure is based on the village. Donna J. Young (2006, p. 53) observes that "[while] Goa's rulers may have changed from time to time, the attachment and fidelity of Goans to their village is greater than their loyalty to the rulers." Hence, one of the most distinctive features of Goan society is the millennial institution of the gauponn or comunidade. Correia Afonso (1991, p. 4) remarks that the village community is one of Goa's oldest institutions, as it is in the rest of India. It is the starting point of the Goan's economic, social, educational and cultural activities. He goes on to add that it is one of the most important Indo-Hindu institutions that survived the Portuguese regime. Almeida (1958, p. 9) says that already in the ancient Book of Manu there are references to the villages or communities as being small independent states with a democratic organization, or panchayat, whose 
people would meet under a tree, the vol, to discuss the matters of the community. These villages, or gaos, were organized in neighbourhoods called vaddes. Even today, says Olivinho J. F. Gomes, "the real Goa lives in its villages, now considerably urbanized and fast becoming part of modern urban culture, yet retaining jealously its unique rural characteristics" (1987, p. 7).

Figure 1 - O Panchayat.

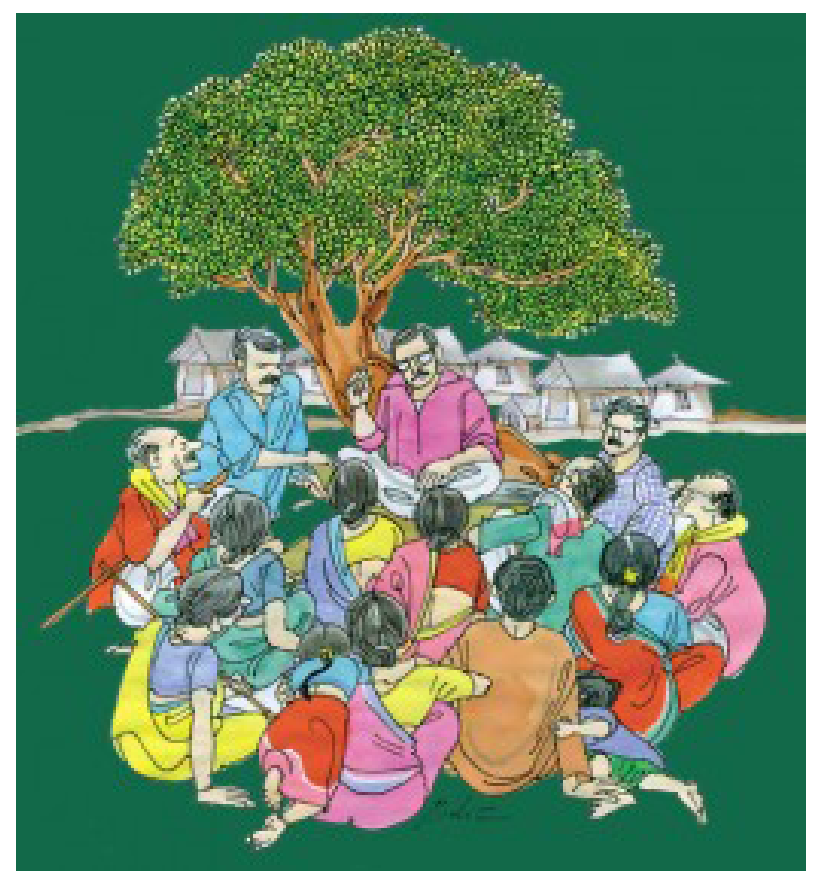

Source: http://hubpages.com/politics/PANCHAYET-rural-selfgovernment-in-India-WHAT-AND-HOW

Many studies of individual villages have been undertaken through time in the different languages of Goa. Among them, Aldeia de Assagão. Subsídios para sua História (Gomes Catão, 1974); A Aldeia de Assolnã (Almeida, 1958). More recently, Village Anjuna (Dominic P. F. Fernandes, 2015); Mapusa, Yesterday and Today (Dominic P. F. Fernandes, 2012); Land of the Salt Trees (Fr. Nascimento J. Mascarenhas, 2012); Unravelling History. The Village of Arossim, Goa (Themistocles D'Silva, 2015). Two of the most important studies on the Goan village are Olivinho Gomes's Village Goa: A Study of Goan Social Structure and Change (1996) and Villages of Goa in the Early $16^{\text {th }}$ Century (2009), by B. H. Baden Powell. 
In turn, the village is so central to Goan literature in all its languages because of its nurturing quality. Says Fernandes about his native village of Anjuna:

From the day I was born, Anjuna has given me its love and affection. It has fondled me in its lap and owned me. As a child, it allowed me to play in its red mud. It threw me on its stones and immediately picked me up and embraced me with love. It made me sit at the top of the trees and fanned me with its fresh breeze. It fed me with morsels of rice and tender coconuts, and gave me the strength to grow. It dipped me in coconut toddy and cashew juice and left their aroma in me. It took me to its chapels and churches and taught me to follow religion and ethics. It helped me to celebrate Catholic feasts and Hindu festivals. It took me by my hand and guided me to climb the stairs of school and thus illumined my mind. It threw me into its rivulet and taught me to swim. It balanced me on my bicycle and taught me to ride it, which made it easier for me later to ride a motorcycle. It controlled me at the wheel and guided me to drive a car. So, how can I forget my Anjuna the birthplace, which has given me so much, and much more? (FERNANDES, 2015, p. 13)

Though the number of short stories from Goa, written in its four languages and in which the village is a structuring element of the narrative is vast, in the present paper, the focus will be on four of them: "Home", a short story in English by Nisha da Cunha (1934-), who has written several books of short stories on the Goan village; "The Legacy of Love" (1965), a short story in Marathi by Laxmanrao Sardessai (1904-1986), a prolific writer both in Marathi and in Portuguese; "Marangel”, a short story in Konkani by Chandrakant Keni (1934-2009), both critic and short story writer, and "Hope" (1963), a short story in Portuguese by Vimala Devi (1932-), short story writer and poet.

While the fictional time of these short stories covers different historical periods, in the nineteenth and in the twentieth century respectively, before and after Goa's integration into the Indian Union, what defines the illustration of the village, as will be presently argued, has to do, mainly, with the character's perspective and position within the local village social stratum.

Phil Cohen (1997, p. 29) argues that community, like citizenship, has become a buzz word nowadays. He remarks that in many narratives on the community, like novels, soap 
operas, movies, commonly two images emerge. While for some, the term community espouses "an ideal associated with sharing and caring for others, realized in institutions and practices of popular self-government and grass roots organizations", for others it is no more than "a smokescreen for the maintenance of particular forms of social inequality, exclusion and injustice" (COHEN, 1997, p. 31). Along the same lines, in this paper, some of the questions to be addressed, regarding the way these stories illustrate the Goan village and its countryside, are the following: What are the plots through which life in the village is articulated? Are villages narrated as a sanctuary when compared to advancing urban society and, therefore, present a little world of our own with their internal logic and manners, or do they affirm traditional patterns of belief that, at times, might prove to be suffocating, or both? In other words, is the Goan village still or has it ever been "what has come to be known to the rest of the world as a Goan way of life, an authentic, unhurried life, [...] marked with the joy of living', still unpolluted by vicious forces..." (GOMES, 1987, p. 7).

\section{The Idyllic Village and Its Surrounding Countryside}

Tuan says that place exists at different levels. He defines the homeland or village "as an important type of place at the medium scale. It is a region (city or countryside) large enough to support a people's livelihood" (TUAN, 1977, p. 149). The word homeland brings together the person's own house as well as the community where it is placed. Also, says Tuan (1977, p. 171), houses and streets and villages per se do not create a sense of place, but "if they are distinctive, this perceptual quality helps the inhabitants develop the larger place consciousness" (TUAN, 1977, p. 149).

This is the case of Nisha da Cunha's short story "Home" (2002) whose plot is built around the indissoluble link between the home and the village, and in which each nook of the house and the street of the local village are tinged by an emotive attitude that reveals the main character's desire to be attached to the place. The action takes place, presumably, in the nineteenth century since it brings to mind the sleepy village of a preindustrial society. It starts in media res in the style of the oral tradition, in which facts are narrated, in a run on fashion: 
And once upon a time in a little village called Arpora there was a lady called Angela and she built a house near a chapel and she built a kitchen and two large bedrooms and a large sitting room and a dining room, and a room for the altar and the saying of the prayers and a balcao to wait on. (CUNHA, 2002, p.18).

The name of the story, "Home" refers both to the house being built by Angela, the main character, near her mother's own home, as well as the village of Arpora. Her choice of a small and uneventful village to settle down, after having been abroad in Portugal, turns it into a place worthier than any other in the universe. The idyllic quality of the village is reinforced by the opening words of the narrative, "once upon a time", as well as the fact that Angela is a "lady", and no ordinary woman. However, there is no happy ending to the story, and as it is characteristic of Da Cunha's narratives, the story shows both the female character's strength as well as her grieving, as she tries to turn the village of Arpora into her permanent home.

Tuan (1977, p. 152) says that religion can either bind a people to a place or free them from it. Talking about the village of Chandor, Gomes (1987, p. 181) points out that due to divisions of caste, solidarity among the Christian segment of the village population is sometimes diffuse. However, despite any kind of rivalry among the villagers, the local Church of Our Lady of Bethlehem imparts a congregational unity to all:

...the church evokes the reverence of all the communities, co-existing peacefully in the village, including the nonChristians. Such is the dominant and all-embracing influence of the Church in the affairs of the village. The bell tolling from the Church spire marks time for the various activities of the villagers, irrespective of creed" (GOMES, 1987, p. 182).

In a likewise manner, Angela's house is close to the chapel of Arpora, one of the main landmarks of the village that qualifies it not only as a picturesque place but, more important than that, as a blissful location. Also, as suggested by Gomes, it makes Angela's house even worthier since it will be within earshot of the chapel's bells that confer sanctity to the place.

The narrative develops as the construction of the house advances. The special care with which Angela chooses the furniture emphasizes the importance she attaches to her home 
and her village as well as her desire to turn it into a place of security and nourishment not only for herself but also for her family. In order to buy the different accoutrements for its many rooms, she goes to the nearby villages, indirectly revealing that they are not necessarily isolated or secluded but that each village is interconnected with the neighboring settlements. She first goes to Cuncolim to buy the bed because the workers there made "beautiful four-poster beds and chairs and tables and cupboards and they carved apples and pomegranates and animals and birds..." (CUNHA, 2002, p. 18). Then she goes to Girim "and got some beautiful basket work chairs for the little garden with four great pillars" (CUNHA, 2002, p. 18). The furniture she chooses is both solid, to last for the future generations, and stylish imitating the grandeur of the great house. But more than the furniture, what turns this new house into a home is the fact that she builds an altar room. Tuan explains the symbolical meaning of the altar room in the family home in the following terms:

The altar or family hearth symbolized sedentary life. It must be placed on the ground, and once established, it could not be moved except as the consequence of unforeseen necessity. Duty and religion required that the family remain grouped around its altar; the family was as much fixed to the soil as the altar itself (TUAN, 1977, p.153).

The altar room stands for Angela's decision to settle down in Arpora. It is a common practice in Hindu houses to have an altar room where the family ancestors are worshipped together with the deities. Along the same lines, and revealing religious and cultural syncretism, Angela brings over from her mother's house "a crucifix and statues of the Madonna and her child and St. Francis and St. Sebastian and St. Anthony" (CUNHA, 2002 , p. 18). When the house is ready she puts in the front door a "door knocker in the shape of a lizard" because "a guide had once told her in Portugal that gargoyles help ward away evil spirits from church" (CUNHA, 2002, p. 18). All these symbols point to the centrality of religion in the Goan village. As Gomes observes, "religion is very much deep-rooted in the Goan psyche and pervades the entire life of the Goan [...] It sets the trend and tune of Goans' daily and seasonal calendar and the orientation of their attitudes and outlook on life". (GOMES, 1987, p. 213) 
Also for the house to be called a "home" and the family to be regarded as being native to the place, it is necessary to establish a lineage in the locality and to pass the site of the family from one generation to the next. When all is ready Angela marries and has four sons. Interestingly, the husband never appears in the narrative. It is as if Angela's desire had not been to marry but to bond herself to the village and, to accomplish that, she needed a family and children. Nevertheless, in spite of her effort to preserve the home and the village, there are stronger forces that lead Goans into the diaspora in search for better economic prospects. This is what makes "the fields around the sleepy village become fallow and the lovely homes gradually undergo dismal disintegration" (FERNANDES, 2015, p. 12). Angela's children go along the same path. They do not care much for the house or the village: "As soon as we are old enough [they tell her] we shall leave here and this gloomy dark Arpora and we will never come back here" (CUNHA, 2002, p. 19). Only one of them, Antonio, promises that he will marry and live there too. Angela dies alone, clinging to the house and the village, and is buried at the local cemetery.

Antonio returns to the house only when he has married the woman of his choice in his late fifties. But the house and the village look oppressive to the new bride who decides to go away. However, Antonio stays and goes on with his mother's work and the village's tradition: "home is where you start from and I started from here. I shall stay here" (CUNHA, 2002, p. 21). Antonio and his mother share a profound attachment to the homeland, to the village. Where others, like Antonio's wife, see darkness and oppression, he sees "an archive of fond memories" (CUNHA, 2002, p. 21) that inspires the present and gives confidence in the future. As Tuan points out "place is permanent and hence reassuring to man, who sees frailty in himself and chance and flux every where" (TUAN, 1977, p. 154).

Villages are immersed in rural life; they are surrounded by an apron of land that is as sacred as the village itself and is many times represented as a perfect landscape of cultivated fields, with trees scattered here and there. Tuan (1977) explains that "a profound sentiment" for the land has also been shared by all communities in all historical times and persists even today, in particular in places isolated from the traffic of civilization. This deep attachment to the village and the land 
resurges in the literature from Goa with great force in the short story "The Legacy of Love"2 (1965) by Laxmanrao Sardessai, at a time when "great industrial and political changes threatened the fixed landscape" (Melo e Castro, 2015, vol. 1, p. 33), like mining, urbanization and the integration of Goa to the Indian Union. As Melo e Castro (2015, vol. 1, p. 33) goes on to say, the story has "a parable-like quality" in the sense that its plot establishes a counterpoint between two interpretations of the land: as a valuable good, as seen by a bhatkar (a landlord), and a source of spiritual sustenance, as seen by a Brahmin farmer who, since his youth, has felt bound to the soil in a relationship of unfaltering love, because it was the source of all that sustained his life:

I identified myself with the crops and had dedicated my whole being to the farm, to my beloved land. A perfect love! A disinterested love! It wasn't the prospect of wealth that bound me to the soil. If I watered the land with the sweat of my brow it wasn't because it paid me in kind. No. For me life without farming would have been impossible (SARDESSAI, 2015, p.73).

The Brahmin's words sound like Sardessai's reminder to Goans about where the true values of their culture are. Again, as in "Home" by da Cunha, it is the idea that he might not have an heir to whom he might bequeath his land, this legacy of love, which he had inherited from his ancestors, that encourages the Brahmin to marry and raise his own family so that they will worship the land as he had always done. His farm and family symbolize the perfect Goan society:

I married. My house now rang with the happy laughter of a new generation. Life heaped me with joy, and my land, with the greatest joy of all. Everyone deemed it rare to see an estate such as mine anywhere in Goa. My farm symbolised the goodness and generosity of our country. (SARCESSAI, 2015, p. 74).

For reasons not stated in the narrative (perhaps because

2 Translated into English by Paul Melo e Castro. 
He thus arrives at a bhatkar's house after visiting his vast and abandoned landholding in the village of Colém and offers to turn his untilled land, which "had the bereft appearance of a woman deprived the blessing of fertility" (SARCESSAI, 2015, p. 74) into a land of "milk and honey" (SARCESSAI, 2015, p. 72).

After years of hard work, the Brahmin fulfills his promise and the absent bhatkar goes to see his "barren land turned into a leafy orchard" (SARCESSAI, 2015, p. 72). What he sees, however, is neither a bucolic landscape, as if it were a still nature, where man has no place, nor a tamed and dead soil, abused by man, but a land that shows a perfect relationship between man and his environment because it is sacred to him, it is his home.

In an everlasting relationship of love, the Brahmin and his family had watered the land with the sweat of their own brows and nourished it with their own energy and strength sealing an unbreakable bond. He does not regard the trees on the property in terms of how many fruits they might yield to fatten his bank account but as the presence of the divine, as he tells the bhatkar:

Don't you think the religious feeling of us Hindus is closely tied to the notion of the tree? Regard these banana trees, look at their straight white trunks, the dense crown of their leaves. Don't they symbolise the purity and benevolence of the Vedic religion? (SARCESSAI, 2015, p. 76).

If in "Home" da Cunha had sanctified her home and her village with the religious symbols of Christianity, here the old Brahmin resignifies both home and land with the beliefs of Hinduism. As Tuan says, "... [the] rhetoric of sentiment barely alters through the ages and differs little from one culture to another" (TUAN, 1977, p. 156). The rootedness to the soil and pious feelings towards it seem natural to all societies, and in this way, cross any kind of cultural barriers. For both, Da Cunha and Sardessai the village and the land that surround them are home because it is the location where tradition is rooted and history is engraved that will survive for the generations to come.

While in "Home" the narrator is buried at the local cemetery and her son takes up the work upon the house at the point his mother had stopped, in "The Legacy of Love", when the Brahmin dies, he finally becomes one with the soil where he is cremated. In a gesture that sees the land not in terms of 
valuable property, but of tradition and religious value because it stands for home, the bathkar gives the fields away to the Brahmin's family, their rightful owners because they are the ones who actually work on them. At another level, his gesture symbolizes Sardessai's desire that the Goans return to their land, to the village, to home: "I merely said that henceforth this land belongs to you, my children. It is the legacy of that great soul who cultivated it, made it fertile, and sacrificed himself in its interest. Protect this precious legacy, the legacy of love for the land" (SARDESSAI, 2015, p.76). Both narratives complement each other. The image of the village that emerges in them is that of an old community surrounded by a beautiful landscape of cultivated fields that gives shelter to all. In both of them, traditional patterns of belief are not suffocating but reassuring because they give stability and continuation to the place as well as an ultimate signification to the characters' lives since it is their devotion to the place that, as Gomes would say, "self-discipline with all the weight of religious sanction". (GOMES, 1987, p. 213)

\section{Life in Our Village: The Social and Religious Divide}

When we look at a place, in this case a village, we can see it in terms of attachments and connections among the people, and between the people and the place (CRESSWELL, 2004, $\mathrm{p}$. 11). One common image of the countryside village is that of the peasants working together at harvest time and socializing at the local market. The casual observer, says Tuan, may conclude that "the village is one place, a unified community conscious of its identity vis-à-vis neighboring communities". (TUAN, 1977, p. 167) Though this is true, like in any other community, within the village there are firm bonds among its members but also rivalries that establish a difference between "my" village: the place where I live, "our" village: the locale of my own kind of people, in the case of Goa, my community, and "the" village: a social unit I am vaguely aware of as distinct from other adjoining areas (TUAN, 1977, p. 171). These relationships are represented in manifold ways in the short stories that have the Goan village as their main settings. They dramatize different kinds of social junctures and disjunctures in which friendship and enmity go hand in hand, tinged by differences of class, caste and religion. 
"Marangel" 3 by Chandrakant Keni takes place in the village of Cansaulim, roughly after Goa's integration to the Indian Union. Life in the village is presented in terms of the relationship between the narrator, who is now successfully working in a big city, perhaps Mumbai, in a government division that grants passports, and Marangel, an old woman now who, in her youth, had earned her life as the city's bhadel, a porter at the local railway station. Cohen points out that in narratives about the community, "social contradictions are translated into emotionally loaded patterns of interpersonal characterology". (COHEN, 1977, p. 35) In Keni's story, the characters' backgrounds already point to the clear social class divide among the members of the village. What helps characterize the narrator and Marangel are the jobs they perform, which reveal where they stand socially. While the narrator is now a successful city dweller, his memories of Marangel are related to the tasks she had done to earn her living. Therefore, when he meets her after so many years he does not recognize her. Calling herself Maria Angelica now, she leaves her village to go to the city to thank the narrator for a favor he had done her son many years before when, with the passport he had got him, the young man had secured himself a job in the Gulf: "If you hadn't done his passport he would never have done so well in life. In the village he would have just wasted away, she explained further" (KENI, p.15). Her words of gratitude point to the need of young people to leave the stagnant and, at times, stifling life of the village. Their only possibility of progress is by going away.

Her son's job abroad had allowed her to have a decent life in Cansaulim and though she now came in a chauffeur driven car, in the post-liberation years she had been one of the marginal characters of the village, earning her living by toiling someone else's land during the day and carrying the eventual visiting Bombayite's loads when they arrived by train in Cansaulim. Her married life had brought even more hardships into her life when her husband, a toddy taper, had had no qualms about beating her out of jealousy since Marangel had been one of the village's beauties. After she became a widow, she had to work hard in order to bring up her son. And once

3 Translated from Konkani by Augusto Pinto. her son had become successful, her daughter-in-law, a spoiled girl, had come to torment her later in life. Though living and 
working in the countryside, Marangel's life is not pure, simple and innocent because of her contact with nature, but both her material conditions and family relationships point to a life of toiling and suffering.

Her unexpected visit, after so many years, is to hand in to the narrator a parcel with some gifts from her son in Dubai. In it, there was a letter in which Marangel's son thanked him for the favour done years before. But more important than that, he asks him to help his mother if she needs anything while he is far away. The request reveals a tight-knit solidarity among the members of the village community. On the one hand, though not intimate, what leads Marangel's son to contact an otherwise casual acquaintance is the fact that both belong to the same village. On the other hand, this request is highly significant because it goes beyond differences of caste or religion since though never said in so many words the narrator is probably a Hindu, while Marangel is a Catholic. One of the things that calls his attention about Marangel is the fact that nowadays she should call herself "Maria Angélica", a Christian name:

When I was young, it had never struck me that her name was Maria Angelica. I was aware that many Christians had three and even more names, which as time passed by, were amalgamated into a new name altogether. But I was never the one to trouble myself over genealogy (KENI, p. 16).

In spite of differences, there is a sense of easy familiarity between the characters based on mutual respect, as traditional values in the story seem to be tempered by what Cohen defines as "a democratic and secular version of modernity" (COHEN, 1997, p. 38)

Keni represents the village through the deployment of familiar conventions and routines akin to rural life. However, what adds interest to his narrative is the contrast between the village as landscape and as a real life place, in the past and in the present respectively, as seen by the narrator: "It's been so long since I left Cansaulim. Yet, whenever I revisit it and come across a familiar face, the memories of those good old days come flooding back". (KENI, p. 17) He evokes it as "a tiny place" in which "everyone in the village knew everyone else". (KENI, p. 16) The only event that broke the calm of this sleepy village was the arrival of the train: "The railway station 
would burst into activity just before the train arrives. After it departed, a hush would descend. The bazaar was just outside the station and it was a sleepy place really. In the evening, it would wake again" (KENI, p.16). Like Proust's madeleine, what brings to mind one of the fondest memories of the village, are the delicious figs that he gobbled down, with his friends from "the fig tree that grew at the end of the bazaar" (KENI, p.16).

In a likewise manner, its inhabitants, now seen from the distance of many years, are regarded as a "motley group of old men and children" (KENI, p.16), who would listen in awe to the stories, both real and imaginary, of the holiday folks who went to the village in "natty clothes and would sport smart English accents" (KENI, p.16). The innocence of what he calls "the riffraff of the village" goes hand in hand with the generosity of the bhatkars who, the day the coconuts were being plucked, would give one to the children or would set aside ripe mango for them. Though not an egalitarian society, as the reference to the bhadel or the bhatkar would imply, there seemed to be an adherence to some higher principle or values that seemed to contribute to the unity of its members.

These memories of his village as a "peaceful landscape" populated by picturesque people turn into a different kind of narrative when he represents it as "a felt and lived place" (CRESSWELL, 2004, p. 10), in particular when he associates it with Marangel's life. Though everyone in the village knew everyone else, people could be cruel to each other. What leads Marangel's husband to take up drinking are the rumors that circulate in the village about his beautiful wife's waywardness. This combination of the bucolic and the harsh aspects of village life come together in the narrator's evoked image of the jackfruit trees next to the village's bazaar. It was beneath their leafy shade that the bhadels would sit, in the afternoon of the sleepy village, as they waited for the train, consorting among themselves. If the image conveys a certain leisure and conviviality among them, it also shows how isolated they were from the rest of the village people.

Nowadays, however, says the narrator, “Cansaulim isn't the same any longer. The population has gone up and the new generations have taken to new ways of life" (KENI, p. 17). Ironically, he does not seem to see that village life has never 
been so idyllic, in the same way that he also belongs among those who helped change its pace of life.

In turn, "Hope"4 (1963), by Vimala Devi, presents the relationship among the village dwellers from a different perspective. It superimposes two intimate domestic tableaux vivants within the realms of the village of Orlim that portray insurmountable differences of caste between a family of bhaktars and of mandukars at the time of Goa's integration into the Indian Union. Melo Furtado (2000, p. 478) says that the bhatkars were landlords who earned their living from agriculture and farming. These activities were made easy by the class of the mandukars who lived on the land belonging to the bhatkars. While their relationship was apparently an amiable one, despite the divide created by positions of superiority and subservience, "this sort of relationship did not, however, preclude a distinct feudal set-up and a rigid class system" (MELO FURTADO, 2000, p. 478) very much ingrained in the life of Goan villages.

"Hope" recreates this relationship by picturing first the mud hut of the humble family of mandukars where Pedrú, his mother and his sister Margorit, are discussing his future and the family's economic situation that very much depends on what will become of him. He is the first member of his community to have graduated from the local Lyceum. He has done it with the help of his mother and sister who had to work hard in the paddy fields to compensate for the time he spent studying.

Attending the Lyceum meant going beyond the limitations imposed by his caste since this level of education was mainly for the children of the bhatkars who were Brahmins while they are Shudras. His ambition was to move up the social ladder by getting himself a position in the government in order to escape from the harsh rural work. In order to get such a job he still needs the help of the family of local bhatkars who, though very much impoverished, after the death of the father and of the grandmother, they are Brahmins and have connections among the most influential people in the government. Pedrú is thinking of asking the young daughter of the family, Mitzi $b a i$, for help. His mother backs up his decision on the ground

4 Translated from the Portuguese by Paul Melo e Castro. that, traditionally, the bhatkar family has had a paternalistic attitude and has been generous with them: 
"Let's pray the rosary, Pedrú, so that Mitzi bai might find you a job. The sacrifices the two of us have made shall be rewarded. Remember that you're the first from Orlim to attend the Liceu. That should fill us with pride. All our sacrifices were worth it, weren't they, Morgorit? Let's say three Our-Fathers for old Rogin bai, may she rest in the peace of the Lord... Amcheá bapá, tum sorgar..." (DEVI, 2003, p. 2)

However, in spite of Pedrú's mother wishful thinking, as Melo Furtado points out, society in pre-liberation Goa was very conscious of the "...social gap, even more than the economic gap between the serving and the served". (MELO FURTADO, 2000, p. 478) This gap was visible every where in Goan society.

At the other end of the social scale, in the great house of the bhatkar, the young people of the family are also concerned about improving their own social and economic situation but, in this case, following a traditional custom: going to a ball to find a rich husband for one of the family's daughters. Though belonging to different castes, what both families have in common is that they have been left without the man of the family, either because he has died, in the case of the bhaktar, or because he has become a drunkard, as is suggested about Pedru's father. The elder sons are now in charge of their mothers and sisters. Both young men, however, seem insecure in their new roles and, because of that, self-conscious of their position in the local community. While Pedrú has qualms about asking Mitzi bai for help, Roberto, the elder brother, of the bhatkar family, is reluctant to take his sisters to the Clube's dance because they insist on dancing with the pacle (Portuguese soldiers) and he is afraid they might become the laughingstock of the village. Melo Furtado (2000, p. 478) points out that prejudices of casteism surfaced at the point of finding a partner for an arranged marriage. His sister, Mitzi, however, is fully aware of their fraught situation:

"Do you remember when grandmother died, Roberto?" she asked. "You're right, it left us in a bad way. We have to be very careful if we're to save the family name, you're right. I know full well that people are watching, just waiting for us to make a wrong move so they can laugh at our expense. I know full well how very difficult it is for poor girls with no father to evade gossip. But we're sensible girls and we've got you, the very best of brothers. Right, shall we stay at home tonight? How about a game of cards, Roberto? Let's invite cousin Alzira over. We'll have a blast!" (DEVI, 2003, p. 3) 
She reassures her brother that she would rather marry a Shudra, a man from a lower caste, than a paclo, on the grounds that she knew that Europeans did not treat their women well. In the same breath, though, she is totally insensitive to Pedrú's request on the grounds that, being a Shudra himself, he was going beyond the limits of his caste both by treating her like an equal and expecting her to intercede on his behalf so that he would get a job above his situation in life. Melo Furtado explains that class and caste consciousness was so strong that "an individual from a so-called high caste would think twice before as much as even sitting next to an individual from a low caste whether in the House of God or in a public mode of transport". (MELO FURTADO, 2000, p. 478). This prejudice clearly divides the village characters in Devi's short story:

\begin{abstract}
"Ah, on the subject of shudras, do you know who came here earlier to ask us to find him a job? Pedrú. Just picture it! Yes, Pedrú, the son of Salúbrancar ${ }^{5}$ Those people are becoming unbearable. Now he's been to the liceu he thinks he's someone and wants a job. They think they're our equals. Whatever next? He turned up here with lots of bai-faí, addressing me as if we were of his ilk. I put him in his place. He wanted me to ask cousin Josinho to get him a job in the Finance department. Whatever next? His mother and sister are out there in the paddy and he thinks he's a bigwig just because he went to the liceu. He's got some cheek, don't you think?"

Roberto nodded solemnly. (DEVI, 2003, p. 4)
\end{abstract}

Both scenes show that if the economic gap was shrinking, due to changes in the social structure of the village, which were the result of the rich losing their fortune and the poor having access to a better education, the social gap remained the same as ever. The young lady's awareness of her own condition instead of making her more sensitive to Pedrú's predicament, hardens her even more, fearing, perhaps, that interceding for somebody from a lower caste might make her lose caste in front of the people of the village, at the time that it is not in the best interest of her own class: it would be the wrong move that might lead people to laugh at their expense.

5 Salú, who likes white wine (konk.). Note by Paul Melo e Castro.

6 Exaggerated respect. Note by Paul Melo e Castro. Nonetheless, it might be argued that she had already gone down the social scale not only due to the privations at home, but also because her eligible candidates were not members of other patrician families, but Portuguese soldiers who, though 
white and considered as people of rank in Goa, back home in Portugal they were ordinary people.

Far from representing life in the village as a little life of our own, governed by harmony and a principle of unity that goes beyond local differences, and leads people to live like good neighbors, it reveals unconquering social barriers. While the people in the big house cling to the past splendors of the family and try to live according to a social ethos that tends to disappear, the people from the village fight hard to traverse the social space that separates them from better living conditions. The tension produces a conflict that tinges the relationship of the people in the village and turns it into a far from idyllic place.

In "Marangel" the characters reach out to each other in spite of belonging to different communities. There is a sense of gratitude for favours done in moments of need. In "Hope", on the other hand, differences of caste seem to be impossible to overcome. While the people from the great house see their village and its people in terms of permanence and boundedness, because they are afraid of losing their stand in society, the mandukars see it in terms of openness and change (CRESSWELL, 2004, p. 40). What both stories have in common, however, is that once we look at life in the village closely, the landscape stops being a still nature and becomes a real life space and the people that populate it are far from being colorful characters.

\section{Final Words}

The stories analyzed in this paper about the Goan village are like the threads of an infinite yarn. They are all about real life villages that can be pinpointed in a map of Goa. As already argued, these villages are immersed in rural life; therefore, telling about the village also means telling about its surrounding countryside and vice versa. Says Tuan "the clustered village stands out in the landscape. Approaching a rural settlement we can see the silhouette of houses and trees rising above the cultivated fields". (TUAN, 1977, p. 169) They form an indissoluble unit.

The stories are recreated through plots that both complement and contradict each other. Some of the narratives reminiscence about a gone back era when life was apparently 
peaceful, even innocent, and there is a desire to turn the village today into a place that will allow its dwellers to lead undramatic but quiet and secure lives, as in past times. Others show the villages riveted by social and cultural conflicts, in particular due to conflicts of caste or religion. In turn, the fictional time of the narratives recreate Goa during the time of the Portuguese colonization and after. They are narrated by characters who assume different perspectives either because they have lived in other countries and come back to settle down in Goa, or because they have long resided in other Indian cities but have kept their ties with the village, or have never left the villages and are willing to flee from them. Besides, they belong to different communities within Goan society: they are Catholics or Hindus, Brahmins or Shudras, bhatkars or mandukars. Their vision of the village very much depends on their own predicament and place within its social hierarchy. While for some, life has no meaning outside the village, because they feel bonded to the land, as in the case of "The Legacy of Love", or because the village protects them against the big world as in "Home", for others life in the village can prove to be suffocating due to the fact that the rigid class and caste system does not allow them to better their own living conditions as in "Hope". Therefore, for some of the characters, the diaspora seems to be the only alternative for a better life as in the case of "Marangel". Each one of the stories presents a little outcome that combined do not present a final denouement and ultimate statement about village life in Goa, but helps characterize it in all its complexity.

\section{REFERENCES}

ALMEIDA, José Julião do Sacramento. A Aldeia de Assolnã. Esboço Histórico, Arqueológico e Biográfico. Lisboa: Ed. Padre José Cristovão Evaristo Almeida, 1958.

AFONSO, John Correia. To Cherish and to Share. The Goan Christian Heritage. South Asian Studies Papers, no 9. Goa: Goa Continuity and Change. Edited by Narendra K. Wagle and George Coelho, University of Toronto, Centre for South Asian Studies, 1995. 
CHAMBERLIN, Edward J. If This Is Your Land, Where are Your Stories? Finding Common Ground. Canada: Vintage Canada, 2004.

COHEN, Phil. Beyond the Community Romance. Soundings Issue 5, Spring, 1997.

CRESSWELL, Tim. Place, a Short Introduction. London: Blackwell Publishing, 2004.

Da CUNHA, Nisha. Home. Modern Goan Short Stories. Luis S. Rita Vas, ed. Mumbai: Jaico Publishing House, 2002.

DESAI, Nishtha. Lusotopie 2000 : 469-476.

DEVI, Vimala. Hope. [1963] Monção. Lisboa: Escritor, 2003.

FERNANDES, Dominic. Village Anjuna. Goa: Goa1556, 2015.

GOMES, Antonio. The Sting of Peppercorn. A Novel Set in Goa. Goa: Goa 1556, 2010.

GOMES, Olivinho. J. F. Village Goa. A Study of Goan Social Structure and Change. New Delhi: S. Chand \& Company, 1987.

KENI, Chandrakant. Marangel. Goan's Goa. An Anthology of Konkani Short Stories. Translated into English by Augusto Pinto. (manuscript).

MELO e CASTRO, Paul (ed.). The Lengthening Shadow. An Anthology of Goan Short Stories. Vol. 1. Goa: Goa 1556, 2015.

MELO FURTADO, Edith. Reacting to a Transition. The Case of Goa. Lusotopie 2000 : 477-486.

PANDIT, Heta. Dust and Other Short Stories from Goa. Porvorim, Goa: Heritage Network, 2002.

RAI, Prava. Into the Dark Heart. Inside/Out. New Writing from Goa. Goa, Goa 1556, 2011.

RANCIERE, Jacques. A partilha do sensivel: estética e politica. Trad. Mônica Costa Netto. São Paulo: EXO experimental org: Ed. 34, 2005.

SARDESSAI, Laxmanrao. The Legacy of Love. [1965] The Lengthening Shadow. An Anthology of Goan Short Stories Translated from the Portuguese. Vol. 2. Paul Melo e Castro editor and translator. Goa: Goa 1556, 2015. 
SHARMA, M. Differences between Villages in Ancient India and Villages Today. Available at <http://www.yourarticlelibrary. com/difference/difference-between-villages-in-ancient-indiaand-villages-of-today/41296/>. Accessed on 07/11/2015.

TUAN, Yi Fu. Space and Place. The Perspective of Experience. Minneapolis: University of Minnesota Press, 1977.

YOUNG, Donna J. Defining Goan Identity. Thesis, Georgia State University, 2006. <http://scholarworks.gsu.edu/history_ theses/6>. 


\section{Resumo}

Se Goa é a sua terra, quais são suas histórias? Narrando o vilarejo, narrando o lar

Goa, Índia, é uma comunidade multicultural com um vasto arquivo de narrativas em concani, marata, inglês e português. Enquanto o concani, na sua versão em devanagari, e não no alfabeto romano, é a língua oficial de Goa desde 1987, há também muitas narrativas em marata, a língua do estado vizinho de Maharastra, em português, o legado da presença portuguesa em Goa desde 1510 até 1961, e em língua inglesa, resultado da colonização britânica da Índia até 1947. Essa situação já revela que a relação entre essas línguas e culturas é muitas vezes conflituosa em nível político, cultural e literário. Por sua vez, elas não são unidades separadas, mas estão profundamente relacionadas no sentido que histórias contadas em uma língua são complementadas ou contestadas quando narradas em outra das linguas de Goa. Uma maneira de relacioná-las em um diálogo significativo é através de uma metáfora em comum que nos ajude a expandir o nosso entendimento das afinidades e diferenças culturais e literárias em Goa. Neste artigo, a metáfora em comum para melhor visualizar a complexa tradição literária goesa, nas suas diferentes línguas, será a do vilarejo uma vez que esse tipo de comunidade é central na estrutura social não somente de Goa, mas da Índia e, por isso, sempre está presente em muitas narrativas literárias, embora de perspectivas, ora complementares, ora contraditórias.

Palavras-chave: Goa, plurilinguismo, literatura, vilarejo. 